\title{
Course-Based Research: A Vehicle for Broadening Access to Undergraduate Research in the Twenty-First Century
}

Prajukti Bhattacharyya, University of Wisconsin-Whitewater Catherine W. M. Chan, University of Wisconsin-Eau Claire

Rocio R. Duchesne, Aditi Ghosh, University of Wisconsin-Whitewater

Steven N. Girard, Jonah J. Ralston, University of Wisconsin-Whitewater

\begin{abstract}
The traditional model of undergraduate research is less effective for engaging students who have little or no previous exposure to research, are unfamiliar with available research opportunities, or face financial or time constraints that prevent them from engaging in co- or extracurricular activities. Given today's changing student demographics, models such as course-embedded research need to be explored so that undergraduate research participation may be broadened across disciplines. This article describes how a community of practitioners was created to infuse research in courses at both two- and four-year campuses, with four examples of courses with embedded research activities. Discussed are strategies for implementing discipline-specific research activities at all levels of the undergraduate curriculum to expose a broader student population to the benefits of mentored research.
\end{abstract}

Keywords: broadening participation, community of practitioners, course-based undergraduate research, CUREs, curriculum development, inquiry

doi: $10.18833 /$ spur/3/3/7

The benefits of participation in undergraduate research (UR), especially for students from minoritized backgrounds in terms of retention, graduation, deep learning, and self-efficacy, have been well documented (Bhattacharyya, Chan, and Waraczynski 2018; Chan, Bhattacharyya, and Meisel 2018; Mandernach 2015; Sweat et al. 2013). The University of Wisconsin-Whitewater embraces the culture of faculty-student collaborative research. However, even though students from minoritized backgrounds have engaged successfully in research early in their college careers (Bhattacharyya et al. 2018; Chan et al. 2018), significant barriers still exist. These include, but are not limited to, a lack of awareness of research opportunities on campus, limited understanding of the academic benefits of mentored research, and the various activities constituting "research" in different disciplines (Bangera and Brownell 2014). Financial constraints, personal barriers, and limited time for co- or extracurricular activities can compound those barriers.

Conducting course-based research might help engage students in research that they might not otherwise experience. This is especially effective in exposing students at twoand four-year campuses to research early in their college careers. Course-based research, especially in laboratorybased courses in science, technology, engineering, and mathematics (STEM) courses, is becoming increasingly popular for helping to address these barriers. Course-based undergraduate research experiences, or CUREs, have been formally defined (Auchincloss et al. 2014, 31) as courses “. . . in which students address a research question or problem that is of interest to the broader community with an outcome that is unknown both to the students and to the instructor." Studies show that engagement in CURE can broaden UR participation (Bangera and Brownell 2014) and increase graduation rates (Rodenbusch et al. 2016) in STEM fields. Stanford and colleagues (2017) found that students in non-STEM disciplines experience similar benefits from participating in UR as their STEM counterparts 
and asserted that UR opportunities should be expanded to include more non-STEM students.

Teaching research-infused courses is different from mentoring UR (e.g., Auchincloss et al. 2014). The scope of course-based research is limited due to time constraints and the range of student preparation and backgrounds, and therefore faculty expectations of the quality of research output has to be adjusted accordingly. Group work and student-student interactions are more common in researchinfused courses, as opposed to one-on-one mentoring common in traditional undergraduate research.

However, despite these differences, the learning gains from course-embedded research are well worth the time invested in planning and teaching such courses (e.g., Alkaher and Dolan 2014; Corwin, Graham, and Dolan 2015). It lets students critically evaluate alternate ideas for themselves, allows them to look at the bigger picture, and empowers them to empirically test claims. It allows students to apply course content to real-world problems, and prepares them for the workforce or postbaccalaureate studies.

At times, course-embedded research can be even more beneficial than mentored UR. In geography, for example, most UR students participate in fieldwork (Harris and Tweed 2010). However, although fieldwork develops data collection and reporting skills (Hill and Woodland 2002), it rarely generates new disciplinary knowledge (Harris and Tweed 2010). Thus, students seldom engage in the complete research process, from formulating research goals and hypotheses to drawing conclusions (Harris and Tweed 2010), as they might experience from participating in course-embedded research. Course-based research activities emphasize the "learning by doing" pedagogical model over traditional lectures and therefore can also help reduce performance gaps (e.g., Freeman et al. 2014) in STEM courses. Similarly, the phenomenon of "grade penalties" in traditional lecture-based STEM courses (e.g., Huberth et al. 2015; Koester, Grom, and McKay 2016; Matz et al. 2017), where the grades of women and students from underrepresented demographics can be lowered by a quarter to a full letter grade than their expected grades based on average GPA, can also be minimized by engaging students in research activities.

\section{The "Research across Curriculum" Project}

CUREs can expose a broader range of students to mentored research, which aligns with the strategic plan at the University of Wisconsin-Whitewater. Therefore, the "Research across Curriculum" (RAC) project was initiated-a learning community of practitioners for faculty/staff interested in implementing/expanding course-embedded research. RAC was funded by a campus Strategic Initiatives grant during the 2018-2019 academic year. Fifteen faculty members, including two from a two-year branch campus, constituted the RAC cohort. Participants included early-career as well as late-career faculty (see Table 1) and came from diverse disciplinary backgrounds.

Twelve participants revised their existing courses, whereas three created new research-infused courses in their disciplines. Most courses enrolled 10-25 students and were delivered face-to-face with a laboratory or discussion component. Table 2 summarizes faculty disciplines, course name, range of student enrollment numbers, and a brief description of the project or inquiry-based activity for courses either created and/or revised by the RAC cohort as part of the project.

Implementing CUREs as formally defined (e.g., Auchincloss et al. 2014) may be more difficult in courses without a dedicated work-time component (e.g., a laboratory). Logistical issues, such as high enrollment and a wide range of student background and academic preparation, can also make CURE implementation challenging. In addition, different disciplines define "research" differently. For example, the online Merriam-Webster Dictionary (Merriam-Webster 2020), defines research as “. . . studious inquiry or examination, especially: investigation or experimentation aimed at the discovery and interpretation of facts, revision of accepted theories or laws in the light of new facts, or practical application of such new or revised theories or laws." Although this may not necessarily be how research is defined by scientists (e.g., Spell et al. 2014), more than one RAC participant chose to follow this definition of research in their courses and emphasized the process of research over addressing novel questions or producing publishable data or new disciplinary knowledge. As one participant from the social sciences stated:

... my emphasis is more on the application of proper methods to questions the students find interesting ... I do not ask students to focus extensively on pushing the boundaries of (disciplinary) knowledge and pursue original research suitable for peer-reviewed publication ... I share the common concern about the "replication

TABLE 1. Experience of Faculty Participants in the RAC Project

\begin{tabular}{|l|c|}
\hline $\begin{array}{l}\text { Number of years teaching } \\
\text { on campus }\end{array}$ & $\begin{array}{c}\text { Number of faculty in } \\
\text { RAC cohort }\end{array}$ \\
\hline Less than 1 year & 2 \\
\hline $1-5$ years & 5 \\
\hline $5-10$ years & 3 \\
\hline $10-15$ years & 3 \\
\hline More than 15 years & 2 \\
\hline
\end{tabular}

\begin{tabular}{l|l|l} 
Spring 2020 | Volume 3 Number 3 & 15
\end{tabular} 
TABLE 2. Overview of RAC Courses

\begin{tabular}{|c|c|c|c|c|c|}
\hline Discipline & Course name & Campus & Course level & Number of students & Research project(s)/question(s) \\
\hline $\begin{array}{l}\text { Applied } \\
\text { Mathematics }\end{array}$ & $\begin{array}{l}\text { Mathematical } \\
\text { Modelling }\end{array}$ & Four-year & Advanced & $\begin{array}{l}\text { Fewer than } \\
10 \text { students }\end{array}$ & $\begin{array}{l}\text { Students focused on ischaemic liver injury, } \\
\text { lake eutrophication, and predator-prey } \\
\text { relationship in upstate New York. }\end{array}$ \\
\hline Biology & $\begin{array}{l}\text { Biotechnology } \\
\text { Lab Methods II }\end{array}$ & Four-year & Advanced & $\begin{array}{l}\text { Fewer than } \\
10 \text { students }\end{array}$ & $\begin{array}{l}\text { Based on background readings on the structure } \\
\text { and function of a specific protein, students } \\
\text { identified amino acids in that protein that would } \\
\text { mutate and predicted how those mutations } \\
\text { would affect the function of the protein. }\end{array}$ \\
\hline Chemistry & $\begin{array}{l}\text { Inorganic } \\
\text { Chemistry }\end{array}$ & Four-year & Advanced & $15-25$ students & $\begin{array}{l}\text { Students designed a unique approach to gener- } \\
\text { ate zinc oxide }(\mathrm{ZnO}) \text { nanostructures onto glass } \\
\text { substrates based on work by previous students } \\
\text { in the course. }\end{array}$ \\
\hline Communication & $\begin{array}{l}\text { Special Topics: } \\
\text { AR for Mobile } \\
\text { Web } \\
\text { (new course) }\end{array}$ & Four-year & Advanced & $10-15$ students & $\begin{array}{l}\text { Students designed and developed an augment- } \\
\text { ed reality or mixed reality web project using } \\
\text { the technologies learned in the course. }\end{array}$ \\
\hline English & $\begin{array}{l}\text { Intermediate } \\
\text { Composition }\end{array}$ & Two-year & Intermediate & $15-25$ students & $\begin{array}{l}\text { What makes a good college writing } \\
\text { assignment? }\end{array}$ \\
\hline English & $\begin{array}{l}\text { Special Topics: } \\
\text { American } \\
\text { Gothic } \\
\text { (new course) }\end{array}$ & Two-year & Introductory & $15-25$ students & $\begin{array}{l}\text { Students created an anthology of primary and } \\
\text { secondary sources on American Gothic. } \\
\text { Students wrote a "day in the life" diary entry } \\
\text { from the point of view of a character referred } \\
\text { to in the texts. }\end{array}$ \\
\hline $\begin{array}{l}\text { General } \\
\text { Education }\end{array}$ & $\begin{array}{l}\text { Global } \\
\text { Perspectives }\end{array}$ & Four-year & Introductory & $\begin{array}{l}\text { More than } \\
35 \text { students }\end{array}$ & $\begin{array}{l}\text { Students generated questions based on their } \\
\text { interests. }\end{array}$ \\
\hline Geography & $\begin{array}{l}\text { Global } \\
\text { Environmental } \\
\text { Challenges }\end{array}$ & Four-year & $\begin{array}{l}\text { Introductory } \\
\text { course for } \\
\text { non-majors }\end{array}$ & $25-35$ students & $\begin{array}{l}\text { Can solar/wind farms meet the electric- } \\
\text { ity demands in the southeastern region of } \\
\text { Wisconsin? }\end{array}$ \\
\hline Geology & $\begin{array}{l}\text { Principles of } \\
\text { Oceanography }\end{array}$ & Four-year & $\begin{array}{l}\text { Introductory } \\
\text { course for } \\
\text { non-majors }\end{array}$ & $25-35$ students & $\begin{array}{l}\text { What is the distribution of gastropods (snails) } \\
\text { in the deep oceans, especially around hydro- } \\
\text { thermal vent systems and cold seeps? }\end{array}$ \\
\hline History & $\begin{array}{l}\text { Islam and } \\
\text { Science in the } \\
\text { Ottoman Empire } \\
\text { Travel Study } \\
\text { (new course) }\end{array}$ & Four-year & $\begin{array}{l}\text { Interdisciplinary } \\
\text { travel-study } \\
\text { course for } \\
\text { non-majors to be } \\
\text { offered in future }\end{array}$ & $\begin{array}{l}\text { Not yet offered, } \\
\text { target } 10-15 \\
\text { students }\end{array}$ & $\begin{array}{l}\text { Students will generate questions based on } \\
\text { their interests. }\end{array}$ \\
\hline Marketing & $\begin{array}{l}\text { Marketing } \\
\text { Research }\end{array}$ & Four-year & Advanced & $25-35$ students & $\begin{array}{l}\text { Students conducted content analysis of } \\
\text { marketing job advertisements. }\end{array}$ \\
\hline Physics & $\begin{array}{l}\text { Analog } \\
\text { and Digital } \\
\text { Electronics }\end{array}$ & Four-year & Advanced & $10-15$ students & $\begin{array}{l}\text { Students selected electronics projects with } \\
\text { source materials available online. }\end{array}$ \\
\hline $\begin{array}{l}\text { Political } \\
\text { Science }\end{array}$ & $\begin{array}{l}\text { Political Science } \\
\text { Research } \\
\text { Methods }\end{array}$ & Four-year & Introductory & $15-25$ students & $\begin{array}{l}\text { Students generated questions based on their } \\
\text { interests. }\end{array}$ \\
\hline Psychology & $\begin{array}{l}\text { Research } \\
\text { Methods in } \\
\text { Psychology }\end{array}$ & Four-year & Advanced & $\begin{array}{l}\text { Less than } \\
10 \text { students }\end{array}$ & $\begin{array}{l}\text { Students generated questions based on a } \\
\text { literature search. }\end{array}$ \\
\hline $\begin{array}{l}\text { Public } \\
\text { Policy and } \\
\text { Administration }\end{array}$ & $\begin{array}{l}\text { Public Policy } \\
\text { Analysis and } \\
\text { Advocacy }\end{array}$ & Four-year & Advanced & $15-25$ students & $\begin{array}{l}\text { Students researched a real community } \\
\text { problem in assigned groups. }\end{array}$ \\
\hline
\end{tabular}

16 Scholarship and Practice of Undergraduate Research 
crisis" in social science, and see great value in replicating and extending existing knowledge/theories.

Since the RAC cohort included faculty from both STEM and non-STEM disciplines, research was defined in the broadest possible terms. These may not necessarily align with scientists' definition pertinent to STEM courses in general and lab science courses, such as biology and chemistry, in particular. RAC participants broadly defined research as any scholarly or creative activity(ies) generating new knowledge for students but not necessarily new disciplinary knowledge. However, students were still challenged to formulate their own hypotheses and procedures for data collection and analyses. Participants prioritized the process of research-consisting of research question formulation, literature review, hypotheses generation, project design, data collection, analyses, and syntheses, and presentation of results orally and/or in writing - over creation of specific research products such as generating publishable data in their courses. This was especially true for colleagues from a two-year branch campus, who wanted to introduce their students to the research process early for developing transferrable skills while creating a product for others to use. Participants correlated different steps of the research process and the corresponding skills developed (e.g., critical thinking skills, problem-solving skills, communication skills, and quantitative skills) to the student learning outcomes specific to their courses, and designed appropriate formative and summative assessment instruments following the principles of "Backward Design" (Cooper, Soneral, and Brownell 2017; McTighe and Wiggins 2013; Shortlidge and Brownell 2016) for assessing students' content and skills gains from conducting course-based research activities. The percentage of course grade allocated toward research activities and different assessment strategies adopted by members of the RAC cohort are summarized in Table 3.

The RAC project was loosely structured to engage participants in discussing various aspects of designing research-infused courses during the fall semester with the expectation that they will implement aspects of research in one of their courses during the following spring semester. Accordingly, participants met five times during the fall semester for 90-minute discussion sessions on ways to infuse research in their courses, best practices, challenges faced, and effective solutions. Three follow-up meetings, including one workshop on external funding opportunities, were scheduled during the spring semester. All meetings were complemented by a virtual component using the webex platform to accommodate faculty teaching at the two-year branch campus and/or those who could not travel to the main campus for scheduled faceto-face meetings. These meetings promoted cross-disciplinary scholarly dialogue. The benefits of the regularly scheduled faculty instructor meetings were measured through a survey at the end of fall semester, where 13 out of 14 (or 93 percent) survey participants stated that they are either extremely satisfied (seven participants, or 50 percent) or somewhat satisfied (six participants, or 43 percent).

Examples of comments from participants include the following:

... I've had a fantastic time hearing about other people's ideas and best practices. We never have a chance to kick around ideas like this.

... Topics of meetings are very helpful and colleagues who lead the discussions are so prepared and I have learned a lot from them.

... The group discussion and presentations have been a good opportunity for me to see how research is conducted in other disciplines on campus. Although the approach is not the same as I would take in my area, it helps me to think of ways to apply research to the course I am planning and how to involve students.

Only one participant claimed to be somewhat dissatisfied with the meetings and commented that:

... Most of the discussions so far have lacked a central theme or focus, instead broadly within undergraduate research. Some of the presentations have lacked clear application to my research/teaching. Overall, I have an idea of what kinds of projects people are working on kind of - but lack a clear idea of how we might be able to collaborate.

Participants also were asked how well their individual goals for participating in the project were met during the scheduled meetings, and the responses were overwhelmingly positive (86 percent responding extremely well or very well). Examples of participants' comments include the following:

... I love all the ideas I'm hearing! I'm really trying to gain new best practices for a research methods course and exploring these ideas is really neat. I'm surprised at how much I'm finding it helpful to talk about pedagogies that on the surface are unrelated to my discipline. I look forward to sharing more ideas moving forward and honing them to my course.

. . . I have certainly learned new things, and I have enjoyed interacting with people on campus who I did not know before this project. I had specific goals of developing a research and writing course but have not had as much time to work on it as I had anticipated. That being said, there are some ideas that have been discussed which are likely to be incorporated into my course, and so the project has been useful. 
TABLE 3. Outcomes of RAC Courses

\begin{tabular}{|c|c|c|c|c|}
\hline Discipline & Course name & $\begin{array}{l}\text { Project outcomes } \\
\text { or deliverables }\end{array}$ & $\begin{array}{l}\text { Percentage of total } \\
\text { course grade toward } \\
\text { project }\end{array}$ & Assessment strategy \\
\hline Applied Mathematics & $\begin{array}{l}\text { Mathematical } \\
\text { Modelling }\end{array}$ & $\begin{array}{l}\text { Written reports, oral group } \\
\text { presentations, poster presen- } \\
\text { tations to a campus audience, } \\
\text { and at a professional } \\
\text { conference }\end{array}$ & 75 percent & $\begin{array}{l}\text { Literature review and problem formula- } \\
\text { tion (midterm), group work/participa- } \\
\text { tion, and group presentations used for } \\
\text { formative assessments; written report } \\
\text { and poster presentations used for } \\
\text { summative assessment based on rubrics } \\
\text { made available to students. }\end{array}$ \\
\hline Biology & $\begin{array}{l}\text { Biotechnology } \\
\text { Lab Methods II }\end{array}$ & $\begin{array}{l}\text { Worksheets for recording lab } \\
\text { activities; final research paper }\end{array}$ & 40 percent & $\begin{array}{l}\text { Formative assessment based on lab } \\
\text { performance and lab worksheets, final } \\
\text { papers for summative assessment for } \\
\text { the research component. }\end{array}$ \\
\hline Chemistry & $\begin{array}{l}\text { Inorganic } \\
\text { Chemistry }\end{array}$ & $\begin{array}{l}\text { Lab reports; final project } \\
\text { requiring students to design } \\
\text { a unique experiment; oral } \\
\text { presentation of final project }\end{array}$ & 20 percent & $\begin{array}{l}\text { Literature reviews using scaffolded } \\
\text { worksheets and formal laboratory } \\
\text { reports as formative assessment using } \\
\text { rubrics provided to students. Final } \\
\text { presentation used as summative } \\
\text { assessment. }\end{array}$ \\
\hline Communication & $\begin{array}{l}\text { Special Topics: } \\
\text { AR for Mobile } \\
\text { Web }\end{array}$ & $\begin{array}{l}\text { Choice between developing } \\
\text { augmented reality content to } \\
\text { be viewed on mobile devices } \\
\text { or writing a research paper }\end{array}$ & 35 percent & $\begin{array}{l}\text { Formative assessment based on } \\
\text { assignments designed to build research } \\
\text { skills. Research papers or augmented } \\
\text { reality apps developed by students as } \\
\text { final deliverables used for summative } \\
\text { assessment. }\end{array}$ \\
\hline English & $\begin{array}{l}\text { Intermediate } \\
\text { Composition }\end{array}$ & $\begin{array}{l}\text { A master bibliography and } \\
\text { list of best practices for } \\
\text { developing an academic } \\
\text { writing assignment for } \\
\text { college students that can be } \\
\text { used by college instructors. } \\
\text { Both deliverables created as } \\
\text { group products. }\end{array}$ & 40 percent & $\begin{array}{l}\text { Formative assessment based on } \\
\text { sample writing assignments, master } \\
\text { bibliography graded based on a } \\
\text { three-part rubric. Revised writing } \\
\text { assignment developed by students } \\
\text { provided to another instructor to be } \\
\text { used in his course. }\end{array}$ \\
\hline English & $\begin{array}{l}\text { Special Topics: } \\
\text { American Gothic }\end{array}$ & $\begin{array}{l}\text { Anthology of primary } \\
\text { and secondary sources on } \\
\text { American Gothic. "Day in the } \\
\text { Life" diary entry }\end{array}$ & 55 percent & $\begin{array}{l}\text { Final deliverables assessed according } \\
\text { to written guidelines. Students submit } \\
\text { reflective statement on the research } \\
\text { process, evaluating their own learning. }\end{array}$ \\
\hline General Education & $\begin{array}{l}\text { Global } \\
\text { Perspectives }\end{array}$ & Research paper & 33.33 percent & $\begin{array}{l}\text { Predefined rubric for assessing research } \\
\text { paper as summative assessment. }\end{array}$ \\
\hline Geography & $\begin{array}{l}\text { Global } \\
\text { Environmental } \\
\text { Challenges }\end{array}$ & $\begin{array}{l}\text { Worksheets for gathering } \\
\text { information and data } \\
\text { analyses; sustainability map } \\
\text { for synthesizing information; } \\
\text { story map for public } \\
\text { dissemination; self-reflection } \\
\text { for metacognition }\end{array}$ & 25 percent & $\begin{array}{l}\text { Worksheets and sustainability maps } \\
\text { for formative assessment. Story map } \\
\text { for public consumption assessed as the } \\
\text { final deliverable. Student self-reflection } \\
\text { at the end of semester graded based on } \\
\text { completion. }\end{array}$ \\
\hline Geology & $\begin{array}{l}\text { Principles of } \\
\text { Oceanography }\end{array}$ & $\begin{array}{l}\text { Dataset; results of data } \\
\text { analyses; written summary of } \\
\text { research project }\end{array}$ & 15 percent & $\begin{array}{l}\text { Research summery and deliverables } \\
\text { graded. Pretest and posttest to address } \\
\text { knowledge of research; data; null } \\
\text { hypotheses; randomness; and basic, } \\
\text { central tendency statistics. }\end{array}$ \\
\hline History & $\begin{array}{l}\text { Islam and } \\
\text { Science in the } \\
\text { Ottoman Empire } \\
\text { Travel Study }\end{array}$ & $\begin{array}{l}\text { Research proposal; final } \\
\text { poster presentation; } \\
\text { self-reflection for } \\
\text { metacognition }\end{array}$ & 70 percent & $\begin{array}{l}\text { Deliverables (research proposals, } \\
\text { literature review, posters, etc.) assessed } \\
\text { throughout the semester based on } \\
\text { predetermined rubrics for formative } \\
\text { and summative assessment. }\end{array}$ \\
\hline
\end{tabular}


TABLE 3. (cont.)

\begin{tabular}{|c|c|c|c|c|}
\hline Discipline & Course name & $\begin{array}{l}\text { Project outcomes } \\
\text { or deliverables }\end{array}$ & $\begin{array}{l}\text { Percentage of total } \\
\text { course grade toward } \\
\text { project }\end{array}$ & Assessment strategy \\
\hline Marketing & $\begin{array}{l}\text { Marketing } \\
\text { Research }\end{array}$ & $\begin{array}{l}\text { Data analyses; summary } \\
\text { write-up }\end{array}$ & 14 percent & $\begin{array}{l}\text { Research paper used for summative } \\
\text { assessment using rubric co-developed } \\
\text { by students. }\end{array}$ \\
\hline Physics & $\begin{array}{l}\text { Analog } \\
\text { and Digital } \\
\text { Electronics }\end{array}$ & $\begin{array}{l}\text { Data collection; schematics; } \\
\text { circuit plans; student } \\
\text { presentations }\end{array}$ & 13 percent & $\begin{array}{l}\text { Formative assessment based on project } \\
\text { complexity, parts/tools used, and } \\
\text { timeliness of the project completion; } \\
\text { presentations used for summative } \\
\text { assessment. }\end{array}$ \\
\hline Political Science & $\begin{array}{l}\text { Political Science } \\
\text { Research } \\
\text { Methods }\end{array}$ & Group oral presentation & 20 percent & $\begin{array}{l}\text { Formative assessment through exams } \\
\text { and homework assignments designed } \\
\text { to identify students' capacity to iden- } \\
\text { tify research relationships; summative } \\
\text { assessment based on final group oral } \\
\text { presentation on team research projects } \\
\text { using rubrics shared with students. }\end{array}$ \\
\hline Psychology & $\begin{array}{l}\text { Research } \\
\text { Methods in } \\
\text { Psychology }\end{array}$ & $\begin{array}{l}\text { Written research proposal and } \\
\text { report; oral presentation }\end{array}$ & 30 percent & $\begin{array}{l}\text { Student research proposals, reports, } \\
\text { and presentations used for summative } \\
\text { assessment. }\end{array}$ \\
\hline $\begin{array}{l}\text { Public Policy and } \\
\text { Administration }\end{array}$ & $\begin{array}{l}\text { Public Policy } \\
\text { Analysis and } \\
\text { Advocacy }\end{array}$ & $\begin{array}{l}\text { Group presentations; } \\
\text { policy memos delivered to } \\
\text { community partner }\end{array}$ & 25 percent & $\begin{array}{l}\text { Group work and group presentations } \\
\text { used for formative assessment; final } \\
\text { group presentation and policy memo } \\
\text { used for summative assessment using } \\
\text { rubrics provided to students. }\end{array}$ \\
\hline
\end{tabular}

From these comments, it can be said that the participants found the discussion sessions helpful in planning and designing courses, hearing different ideas and feedback received from the cohort regarding specific issues, and enjoyed interacting with other like-minded people on campus. They also found discussions on CURE pedagogy helpful, as well as learning about how research is conducted in disciplines other than their own.

A one-day workshop was conducted during winter break with discussions on assessment, funding, and interdisciplinary collaboration opportunities, as well as self-care and work-life balance issues. The session on assessing the research portion of the courses was particularly wellattended as it addressed a fundamental dimension of all research-infused course design. Due to the wide variety of courses, both in terms of disciplines and course levels (see Tables 2 and 3), it was not feasible to formulate a uniform assessment standard for all research-infused courses during this project. Also, the participants were not equally familiar with infusing research into their courses. With few exceptions, this was the first time many participants, irrespective of their level of teaching experience (see Table 1), were attempting to infuse research into their introductory-level courses, and that, compounded by a lack of familiarity with research methods used in other disciplines, added to the difficulty of creating a uniform assessment tool to be used campus-wide across disciplines. The scarcity of available reliable and validated "off-the-shelf" assessment instruments (e.g., Shortlidge and Brownell 2016) for non-STEM disciplines also added to the challenge. As Alkaher and Dolan (2014) pointed out, the Classroom Undergraduate Research Experience (CURE) Survey (Lopatto 2010) is one of the most widely used instruments for assessing CURE outcomes. However, this three-part precourse and postcourse survey includes questions on students' attitudes toward science, and, as such, the authors did not believe it could be applicable for assessing student learning gains from conducting research in the context of non-STEM courses such as marketing and English composition.

Other campuses nationwide have also faced this challenge. The Students as Scholars initiative at George Mason University (2020) and the Distinction through Discovery plan undertaken by Florida Atlantic University (2015) are two examples demonstrating the level of administrative and financial support, infrastructure, institutional buy-in, project duration, and faculty commitment necessary for creating institution-wide student learning outcomes from research-infused courses and corresponding assessment instruments. The RAC project was only a first step toward 
forming a cohort of faculty interested in infusing elements of research in their courses, and, as such, developing a uniform assessment instrument for research elements infused in courses was beyond the scope of this initiative. Instead, the RAC participants determined the percentage of course grades to be allotted to the research-related activities for their own courses based on the learning outcomes specific to their courses. Spell and colleagues (2014, Figures 4a and $b, 107)$ demonstrate that the proportion of course time devoted to the research component varies widely depending on whether the course was for majors or nonmajors, as well as on institution type, even within a single discipline (biological sciences). The authors report that 56 percent of the courses they studied devote less than a quarter of course time to research. The variation of percentage grade (13 percent-75 percent) allotted to the research component by RAC participants (see Table 3) is consistent with that reported by Spell and colleagues (2014).

Participants developed and used rubrics for assessing various aspects of research outcomes and deliverables for their individual courses (see Table 3 ) that are aligned with specific course learning objectives following the principles of "Backward Design" (Cooper et al. 2017; McTighe and Wiggins 2013; Shortlidge and Brownell 2016). One faculty member (from marketing) even involved his students in rubric development to encourage student ownership of the projects. The rubrics were shared with students beforehand. One faculty member (teaching oceanography) used pretests and posttests to assess students' knowledge gain on statistical parameters used in research.

One of the most common practices for assessing student outcomes from CUREs is to compare DFW rates between courses with and without a CURE component. However, as Shortlidge and Brownell (2016) pointed out, this can add a self-selection bias to the assessment data if students are allowed to choose a CURE section over a nonCURE section. Comparing DFW rates with statistically valid sample size also requires that the course be offered multiple times both with and without a CURE component, ideally taught by the same instructor. This was not feasible for RAC participants. Seven of the fifteen participants were early-career faculty with fewer than five years of experience on campus (see Table 1). Those faculty did not have adequate opportunities to offer their courses in both CURE and non-CURE formats enough times for collecting DFW comparison data from a large enough sample size. Also, even though all participants were familiar with infusing research into their upper-level courses, this was the first time that participants attempted to infuse elements of research in their introductory or general education courses for nonmajors, including three faculty members who designed new course offerings during the project. This added to the difficulty in collecting valid DFW comparison data with and without a
CURE component for those courses as well. Furthermore, some courses - specifically research methods courses in biotechnology, marketing, psychology, and political science-have always been taught as CURE courses, and, therefore, collecting DFW data from comparable nonCURE sections was not feasible for those.

\section{Final Project Evaluation}

Participants submitted a self-reflection report at the end of the project, in which they described how participating in RAC has benefited them as teachers-scholars. Most participants identified the opportunity for cross-disciplinary dialog and collaboration as major benefits. They also stated that, although they were familiar with CUREs implemented in upper-level courses in their respective disciplines, participating in RAC has encouraged them to infuse research in introductory-level courses as well. As stated by one participant in the final reflection:

... I was skeptical of the whole idea of incorporating research into a general education course, and expected to report back to the group that it was a noble attempt, but best left to majors only in advanced classes. I now have "done a 180" and feel that CUREs will be a possibility for anyone ... . in any class.

Besides the final reflection, participants also provided their syllabi and specific examples of research activities implemented in their courses as tangible project outcomes. Provided below are four examples of research-infused courses, ranging from a general education social science course for nonmajors to an upper-level core course in applied mathematics. The examples demonstrate levels of student autonomy as described in the Research Skills Development Framework (Willison and O'Regan 2007), ranging from "bounded research," where the research boundaries were set by the instructor with limited directions (Level 2 ); through "scaffolded research," where instructors provided scaffolds to shape independent research (Level 3); to "researcher-initiated," where students formulated the research questions and initiated their projects with guidance from the instructor (Level 4).

\section{Research-Infused Course Examples}

\section{Research on Alternative Energy in a 200-Level General Education Social Science Course for Nonmajors}

Global Environmental Challenges (GEOGRPY 252) introduces students to today's most pressing environmental challenges and their potential solutions. This is a threecredit course with no prerequisites that enrolls up to 30 students, including those from minoritized backgrounds, and spans a wide range of majors and class standings.

For the course-embedded research project, students addressed the following question: "Can solar/wind farms meet the electricity demands in the southeastern region 
of Wisconsin?" To address the question, students had to perform the following tasks:

- analyze spatial data to identify suitable solar/wind farm locations,

- calculate how many solar panels or wind turbines could be placed in that area,

- estimate potential electricity production, and

- estimate the number of people that could benefit from such renewable energy sources based on the actual consumption patterns of the population.

To meet these objectives, students worked on three worksheets throughout the semester, each with guiding questions scaffolded on previous knowledge. For example, the first worksheet required them to investigate the physical conditions necessary for wind/solar farms. This information was later used to create a renewable energy suitability map in ArcGIS Online using a ready-made, step-by-step tutorial. At the end of the semester, students consolidated their research findings on an ESRI story map and argued for or against solar/wind energy farms. They publicly shared the story map using a social media platform of their choice, including Facebook, Twitter, and Instagram. This project was worth 25 percent of the course grade and involved critical assessment of data sources, summarization of main points, quantitative data analysis, hypothesis testing, and communication of results to a general audience.

Formative assessment was conducted throughout the semester in the form of three worksheets and a story map. Through these tools, it was evident that the overall course learning objectives were met by the research project and that students gained a deeper understanding of renewable energy and its potential to meet demands. The quality of the answers provided to the questions in the worksheets and the caliber of the story maps demonstrated the critical thinking, analytical, and communication skills gained by the students from the project. Aligning the research activities with the research objectives according to the principles of "Backward Design" (Cooper et al. 2017; McTighe and Wiggins 2013) made the work more meaningful for students.

Such a project can certainly be infused in similar courses at other institutions, including two-year campuses. However, since one of the specific research objectives involved estimating the total suitable area for solar/wind energy, familiarity with ArcGIS Online, or access to necessary technical expertise, is recommended for addressing that objective. A strong and reliable internet connection is also essential for creating the suitability maps without interruptions. Lacking these resources, selected aspects of this research project can still be implemented using another platform such as Google Slides or PodBean. Also, it is important to break down the project into smaller chunks, and to repeatedly and explicitly point out how the project activities help meet the course learning goals and the overarching project goal.

\section{Community-Based Research in a Political Science Course}

The political disengagement of young adults is a wellknown and much-discussed issue, and some practitioners contend that educators can (and should) counter this trend by providing students with learning opportunities that impart the skills, knowledge, and values required by active citizenship (Ferman 2012). Incorporating community-based research into a course, which can increase civic engagement and improve student understanding of complex policy issues (Assendelft 2008), is one way to address this concern.

Community-based research begins with a problem important to the community. By addressing this problem through applied research, the gap between theory and practice can be bridged. Community-based research can be incorporated into policy courses without unduly burdening students or instructors (Goss, Gastwirth, and Parkash 2010). The research experience described here was intentionally designed to minimize the time investment required of the instructor while still providing students with the benefits of problem-based active learning.

Public Policy Analysis and Advocacy (POLISCI 330) is a three-credit, upper-level course required for public policy and administration majors, and for students pursuing a management degree with an emphasis in nonprofit studies. Two sections of the course are compared here: a section in spring 2017 (Section A) in which 30 students researched an issue facing the state and presented their results only to the instructor, and a section in fall 2017 (Section B) in which 31 students researched a problem facing the community and presented their results to both the instructor and a community partner.

For both sections, students were assigned to "policy working groups" of three to five peers. Each group carried out course-based undergraduate research using the following steps: defining a public policy problem, collecting relevant evidence, constructing alternatives for addressing the problem, establishing criteria for evaluating policy alternatives, projecting potential outcomes for implementing each alternative, and selecting (with justification) a preferred alternative. Half of class time was devoted to the project, which accounted for 25 percent of the total grade. Both sections met two days per week, with one day designated for lecture and the other designated for research activities. One week, students would meet with their groups in a computer laboratory to prepare presentations for a step of the policy analysis process, and the following week each group would give a five- to sevenminute in-class presentation for instructor feedback. The 
students' research culminated in the formal presentation of policy memos.

Although Section B incorporated community-based research, the structure of the two sections was similar. Rather than sending students out into the community in Section B, the community was invited into the classroom. The community partner in Section B came to the first class to introduce herself and her agency, explain the problem that the students would be researching throughout the semester, and provide resources. Midway through the semester, she attended student presentations of potential policy alternatives and provided feedback. She again visited at the end of the semester to receive the students' policy memos and to discuss their final presentations. This model of community-based research can be adapted to a variety of similar courses without requiring much additional time and coordination. Also, the community research component was well received by students: student evaluations were highly positive for both sections, but the numeric score was higher for Section B (4.68 out of a possible 5 in Section A and 4.82 out of a possible 5 in Section B). A student who participated in the community-based research sent an email with these positive remarks about the experience: “. . . Your class was one of the first classes I took in all of my college career that felt truly worth it. I actually felt like I learned something that would help me with my career and in the real world."

Providing classroom time for work intended to benefit the community does not shortchange course learning outcomes (Jenkins 2011). Through their community-based research, students develop teamwork skills, critical thinking and problem-solving ability, and information and quantitative literacy. The use of active learning in STEM classrooms is known to result in better exam grades and reductions in course DFW rates (Freeman et al. 2014). Furthermore, research indicates that, although involvement in UR improves retention and performance of all students, students from minoritized backgrounds benefit the most (Jones, Barlow, and Villarejo 2010). A review of DFW rates for the two sections indicates that, in Section A, where students participated in course-embedded research without an applied community component, the DFW rate for students from minoritized backgrounds was 14.3 percent. In Section B, where students participated in community-based research, the DFW rate for those students dropped to 0 percent. Although more data over a longer timespan are needed to determine the exact nature of this relationship, incorporating course-based research addressing a real community problem seems to be a promising avenue for addressing performance gaps.

This example showcases active engagement of students in a public policy course at a four-year university, but it should be noted that it is possible to extend these research opportunities to policy courses taught at two-year campuses as well (e.g., Lovell 2018; Schuster 2018).

\section{Open-Ended Research in an Inorganic Chemistry Course}

Foundational Inorganic Chemistry (CHEM 260) was designed within a CURE framework. Each week, this course meets for three lecture sessions and one, approximately three-hour integrated laboratory and typically enrolls 12 to 16 students.

The three primary course learning objectives were to have students: (1) access, read, and analyze inorganic chemistry literature; (2) acquire and analyze data, preferably obtained from student-designed experiments; and (3) communicate orally and in writing. These objectives were met by linking the lecture and lab sections to a structured series of four overarching experiments conducted throughout the semester:

- light, color, art and creativity in science

- metal complex chemistry

- crystallography/diffraction

- exploratory nanoscience research project

For each of these experiments, an article from the primary literature was selected and a worksheet designed to engage students in research techniques, analysis, and context, either immediately before or concurrently with the laboratory. Thus, students were encouraged to read primary research literature, comprehend the analyses used, and engage in class discussion before conducting experiments. The laboratory experiments emphasized progressive development of research skills and techniques, including laboratory safety, crystallization and purification techniques, and instrumental analyses (UV-Vis spectroscopy, magnetic susceptibility, and X-ray diffraction), culminating in a final student-led project. The first three laboratory reports were worth about 8 percent of the overall grade, with the final research project (a formal laboratory report and an in-class oral presentation) accounting for approximately 12 percent of the overall grade.

For the research project, students designed a unique approach to generate zinc oxide $(\mathrm{ZnO})$ nanostructures onto glass substrates. They received exploratory $\mathrm{ZnO}$ nanostructure data obtained by former students in this course, which included prior scanning electron microscope (SEM) images and the basic synthetic parameters. Using prior student work as exemplars, students must formulate hypotheses regarding experimental modifications and propose a new, independent study to generate a unique nanostructure morphology using an untested set of conditions. Students compiled their reaction conditions together in a shared table to avoid replicating experimental conditions. 
The requirement for students to perform unique experiments, rather than repeat prior students' experiments, was by design. Within the CURE framework in this course, students must leverage prior research to develop hypotheses regarding their unique experimental conditions. In so doing, the students are required to synthesize prior research, along with sometimes conflicting or confusing results, to add their own unique contributions. The students are assessed on their ability to demonstrate and convey this knowledge via formal laboratory reports that are in the same style and format as primary research journals within the discipline (issued by publishers such as American Chemical Society and Angewandte Chemie).

Students performed their proposed experiments during the last three or four weeks of the semester and orally presented their findings to the class on the last week. Following the presentations, students added their data to the communal electronic laboratory notebook that is maintained over each semester, organizing and detailing the various synthetic conditions tested and results obtained, so future students can continue the research project in future semesters.

Anecdotal evidence suggests that students enjoy the CURE framework. Through the student-led project, students take ownership of their work and invest in the outcomes, leading to improved learning. Linking primary literature and a clear overarching research structure throughout the course help students integrate course content. Students feel their work is important and valuable because it contributes to future students' learning. By being engaged in CUREs, students, especially underrepresented and female students, are better prepared for graduate school and researchrelated careers (e.g., Bangera and Brownell 2014; Eagan et al. 2013), and are more likely to pursue those options.

Although embedding independent research in this course required significant planning, a complete course restructuring was not needed. As long as students are familiar with foundational activities before undertaking their projects, similar projects can be implemented in equivalent courses.

\section{Research in a Mathematical Modeling Course}

Mathematics Modeling and Simulation (MATH 381) is a three-credit, mandatory, upper-level course for applied mathematics majors offered every spring semester. Students are expected to have coding skills and a background in advanced calculus and linear algebra. Students in this course learn computational tools needed to apply the method of differential equations and functions to model processes in physics, chemistry, biology, medicine, and finance.

In spring 2019, six students majoring in computer science, applied mathematics, and physics enrolled in this class.
They were divided into three pairs to work on mathematical modeling projects on ischaemic liver injury, lake eutrophication, and the predator-prey relationship in a state park in upstate New York. Students received these topics from the instructor at the beginning of the semester. Since the outcomes of these projects were unknown to both the instructor and the students, this course followed the formal definition of CUREs (Auchincloss et al. 2014).

Traditional lectures on significant topics as indicated in the syllabus occurred during every class session, and lecture-based homework assignments accounted for 25 percent of the total grade. Those assignments were given to develop the students' analytical and coding skills. However, 75 percent of course grades was based on open-ended research projects initiated by students. Students developed appropriate mathematical models for this class to address their chosen research problems using examples provided in the course, and out-of-class help was provided from the instructor as needed. The formulation of a research problem based on a detailed literature review conducted for a month counted as the "midterm" in this course, which was worth 25 percent of the total grade. Students were asked to provide updates on their research progress through biweekly in-class presentations. Those presentations accounted for 25 percent of the total grade. Written reports and oral/poster presentations constituting 25 percent of the total grade were used for final assessment. A written rubric for project assessment based on focus, methodology/evidence, analysis/interpretation, and conclusion was made available to students at the beginning of the semester. This rubric gave them a detailed idea for the grading method. Ultimately, students presented their research on campus at the Spring Undergraduate Research Day, as well as at the Mathematical Association of America (MAA) Wisconsin Chapter meeting in 2019.

This model for course-embedded research can be replicated with few modifications. However, it is recommended that the research questions be clearly outlined to help students better identify the project goals and time required for project execution. Sometimes it can be difficult to assess the performance of each student working in groups and assign a grade to individuals based on their respective contributions. To address this issue, a peer evaluation form was given to each student three times during the semester to assess the contributions of their research partners. The instructor discussed the issue with students receiving low scores and tried to resolve it. In situations when the group dynamics were dysfunctional, the group members were advised to pursue their projects individually.

\section{Discussion: Lessons Learned from the RAC Project}

Even though course-embedded research is more common in STEM disciplines, all students, irrespective of discipline, can benefit from engagement in inquiry-driven 
course activities. Most published examples of CUREs showcase upper-level laboratory courses in STEM disciplines, and the academic benefits of CUREs in STEM disciplines have been well documented. The RAC project successfully initiated cross-disciplinary dialogues and a support structure among faculty interested in infusing research in their courses at both two- and fouryear campuses. Participants stated that they benefited from exchanging ideas with colleagues and felt that researchinfused courses could be implemented without much difficulty in most courses, including introductory-level courses, across disciplines.

Participants did not report having to invest an inordinate amount of time for integrating or implementing researchrelated activities in the courses they revised or created as part of this project. In fact, several participants reported that they are considering infusing research in multiple courses based on their RAC experience. The following comments highlight that point:

... I have gotten a better understanding of CURE and how it applies to my (upper level) course, as well as gaining some new ideas on how to infuse more research into my lower level courses.

. . . I thought research-infusion is only possible for smaller class sizes. But throughout the RAC meetings and based on my interactions with other faculty, I have realized that research component can be infused to any class size given that the expectations should be different based on the student learning goals. I will definitely implement research-infused courses in future and even for non-science majors at a different scale.

This was the first time such a program has been initiated on campus, and assessing student outcomes from researchinfused courses using a uniform assessment instrument across disciplines was beyond the scope of this project. Participants allotted different percentages of course grades toward the research activities in their courses (see Table 3) and developed strategies to assess whether or not learning outcomes specific to their courses have been achieved. Although comparable learning and/or skills gains can be made in both traditional and CURE courses (e.g., Rowland et al. 2012), most RAC participants reported anecdotal evidence of students being more engaged in the research activities. As participants' comments demonstrate:

... I see the value of infusing research into teaching: it gets the students excited, it makes a class dynamic, students are more interested in the topic, and much more.

... [M]y first step was to make the research interesting to my students. Instead of selecting a research topic for them, I asked students to choose the topic based on their own interests. Students loved the approach. One student did his research on military spending and its impact on the American economy. He interviewed two family members who served in the military and one that retired as a U.S. Army Colonel. He said he was really engaged in the project since it was an assignment he enjoyed doing so much.

Participants also reported that having students develop artifacts that can be used by others outside of the course - for example, producing a policy analysis report for a community partner, presenting research to a professional conference, contributing to a common dataset to be used by future students, or creating a college writing assignment for another course-motivated students to produce high-quality work. Future iterations of this project will focus on collecting long-term data on DFW rates from courses taught both with and without a research component, and will also consider creating reliable assessment instruments as a community of practitioners that can be used across disciplines for student self-assessment of learning gains from CUREs.

For faculty and administrators interested in offering more research-infused courses, especially courses at an introductory level, the RAC model can be used for creating a community of practitioners and a support network. The following suggestions developed by the RAC participants can be useful in this regard.

When choosing CURE projects, the following questions could be considered:

- Is the research accessible and interesting/relevant to students? This question is important for motivating students and engaging them in the research process. It can be addressed by asking students to choose their own research projects or take ownership of their projects in other ways.

- What skills are required for research activities, and how might students acquire them? Although the basic steps of the research process are more or less uniform across disciplines, disciplinary variations exist in the ways that research is conducted. Some projects might need prior knowledge of computer coding or the ability to read an electronics schematics, whereas others might require an ability to identify and find reliable primary sources through library research. Knowing the prior skills necessary to conduct the activities, as well as the campus resources that students can access for help, are vital for selecting appropriate projects for a course.

- Can the project be completed within one academic term? Traditional undergraduate research projects are typically conducted over two or more terms (semesters, trimesters, or quarters) during the academic year or over 10-12 weeks of intense research activities during the summer. Course-based projects had to fit within the parameters of a one-term course, and the scope of the 
project had to be adjusted accordingly. It is also essential to start the projects early in the term and provide concrete deadlines for reaching specific project milestones. This can allow for addressing unforeseen setbacks in the project.

- How might this project be assessed? What can be used as measures of "success"? This is by far the most important consideration for research-infused courses, and the RAC participants agreed that aligning the project activities with the overall course learning outcomes and designing appropriate instruments for both formative and summative assessments worked best for their own courses. In all cases, however, the rubrics or assessment guidelines should be made available to students early with clearly described assessment criteria. In courses with projects involving the development of an artifact whose quality determines the "success" of the project, the criteria for assessing the quality of the final product should be made available early in the course and reinforced multiple times during the semester. Student learning outcomes in CURE courses in STEM disciplines can also be assessed using any of the available valid and reliable assessment instruments, such as the CURE survey (Lopatto 2010).

- Is there potential for this research to be presented or published? This can be a consideration for faculty members who seek to combine their roles as teachers and researchers, and who might want to implement CUREs in their courses in a way that will result in student collection of publishable data. Maintaining the quality of research conducted by students with little or no familiarity with the specific research activities needed for publication can be a challenge in this regard. However, this is feasible in an upper-level course with students who have adequate experience and academic background.

Participants also recommended that instructors who are infusing research into their courses for the first time should introduce research in "small doses" in the course instead of changing the entire structure of a course all at once. Small-stakes assignments that will represent a relatively lower percentage of the course grade are appropriate for those infusing research into their courses for the first time. The research components should be introduced early in the term and the objectives made transparent to students. Scaffolding the project is essential so students can build their skills. The scopes of the projects should also be limited and well-defined.

\section{Conclusion}

Course-embedded research has the potential for broadening UR participation and early engagement in research in all disciplines, especially given today's changing student demographic. Furthermore, CUREs can potentially address performance gaps by lowering DFW rates and grade penalties, as well as by motivating and engaging students in their own learning. On campus, an interdisciplinary cohort of practitioners helped identify best practices and challenges for implementing elements of research in both introductory and upper-level courses across disciplines. The participants formulated a list of recommendations for aspiring instructors interested in infusing research in their courses across all disciplines. It can be an effective pedagogical practice at both two-year and four-year campuses, and can be implemented in courses with little difficulty or infrastructure modification.

\section{Acknowledgments}

The authors would like to acknowledge the contributions of all RAC participants and workshop leaders, and the Provost's Office at the University of Wisconsin-Whitewater for providing financial support for the RAC project. The manuscript benefited from the comments and suggestions of two anonymous reviewers and the issue editor.

\section{References}

Alkaher, Iris, and Erin L. Dolan. 2014. "Integrating Research into Undergraduate Courses: Current Practices and Future Directions." In Research Based Undergraduate Science Teaching, edited by Dennis W. Sunal, Cynthia Szymanski Sunal, Emmett L. Wright, Cheryl L. Mason, and Dean Zollman, 403-434. Vol. 6 of Research in Science Education. Charlotte, NC: Information Age Publishing.

Assendelft, Laura van. 2008. "“City Council Meetings Are Cool': Increasing Student Civic Engagement through Service Learning." Journal of Political Science Education 4(1): 86-97. doi: 10.1080/15512160701816150

Auchincloss, Lisa Corwin, Sandra L. Laursen, Janet L. Branchaw, Kevin Eagan, Mark Graham, David I. Hanauer, Gwendolyn Lawrie, et al. 2014. "Assessment of Course-Based Undergraduate Research Experiences: A Meeting Report." CBE-Life Sciences Education 13: 29-40. doi: 10.1187/cbe.14-01-0004

Bangera, Gita, and Sara E. Brownell. 2014. "Course-Based Undergraduate Research Experiences Can Make Scientific Research More Inclusive." CBE-Life Sciences Education 13: 602-606. doi: 10.1187/cbe.14-06-0099

Bhattacharyya, Prajukti, Catherine W. M. Chan, and Meg Waraczynski. 2018. "How Novice Researchers See Themselves Grow." International Journal for the Scholarship of Teaching and Learning 12(2): Article 3. doi: 10.20429/ijsotl.2018.120203

Chan, Catherine W. M., Prajukti Bhattacharyya, and Seth Meisel. 2018. "A Model for Successful Cross-Campus Collaboration for Engaging Potentially At-Risk Students in Mentored Undergraduate Research Early in Their College Career." Scholarship and Practice of Undergraduate Research 1(3): 48-56. doi: 10.18833/ spur/1/3/13

Cooper, Katelyn M., Paula A. G. Soneral, and Sara E. Brownell. 2017. "Define Your Goals Before You Design a CURE: A Call to Use Backward Design in Planning Course-Based Undergraduate Research Experiences." Journal of Microbiology \& Biology Education 18(2): 1-7. doi: 10.1128/jmbe.v18i2.1287

Corwin, Lisa A., Mark J. Graham, and Erin L. Dolan. 2015. "Modeling Course-Based Undergraduate Research Experiences: 
An Agenda for Future Research and Evaluation." CBE-Life Sciences Education 14(1): es1. doi:10.1187/cbe.14-10-0167

Eagan, M. Kevin Jr., Sylvia Hurtado, Mitchell J. Chang, Gina A. Garcia, Felisha A. Herrera, and Juan C. Garibay. 2013. "Making a Difference in Science Education: The Impact of Undergraduate Research Programs.” American Educational Research Journal 50: 683-713. doi: 10.3102/0002831213482038

Ferman, Barbara. 2012. "Educating for Democracy: Reflections from a Work in Progress." Journal of Political Science Education 8: 231-250. doi: 10.1080/15512169.2012.695966

Florida Atlantic University. 2015. "Distinction through Discovery: A Plan in Action." Accessed March 22, 2020. https://www. fau.edu/ouri/qep/about_QEP.php

Freeman, Scott, Sarah L. Eddy, Miles McDonough, Michelle K. Smith, Nnadozie Okoroafor, Hannah Jordt, and Mary Pat Wenderoth. 2014. "Active Learning Increases Student Performance in Science, Engineering, and Mathematics." Proceedings of the National Academy of Sciences 111: 8410-8415. doi: 10.1073/ pnas. 1319030111

George Mason University. 2020. "RS and SaS Courses." Accessed March 22, 2020. https://oscar.gmu.edu/faculty-staff/ rs-and-sas-courses/

Goss, Kristin A., David A. Gastwirth, and Seema G. Parkash. 2010. "Research Service-Learning: Making the Academy Relevant Again." Journal of Political Science Education 6: 117-141. doi: 10.1080/15512161003708210

Harris, Tim, and Fiona Tweed. 2010. "A Research-Led, InquiryBased Learning Experiment: Classic Landforms of Deglaciation, Glen Etive, Scottish Highlands." Journal of Geography in Higher Education 34: 511-528. doi: 10.1080/03098265.2010.486851

Hill, Jenny, and Wendy Woodland. 2002. "An Evaluation of Foreign Fieldwork in Promoting Deep Learning: A Preliminary Investigation." Assessment \& Evaluation in Higher Education 27: 539-555. doi: 10.1080/0260293022000020309

Huberth, Madeline, Patricia Chen, Jared Tritz, and Timothy A. McKay. 2015. "Computer-Tailored Student Support in Introductory Physics." PLOS ONE 10(9): e0137001. doi: 10.1371/journal. pone.0137001

Jenkins, Shannon. 2011. "The Impact of In-Class Service-Learning Projects." Journal of Political Science Education 7: 196-207. doi: 10.1080/15512169.2011.564911

Jones, Melanie T., Amy E. L. Barlow, and Merna Villarejo. 2010. "Importance of Undergraduate Research for Minority Persistence and Achievement in Biology." Journal of Higher Education 81(1): 82-115. doi: 10.1080/00221546.2010.11778971

Koester, Benjamin P., Galina Grom, and Timothy A. McKay. 2016. "Patterns of Gendered Performance Difference in Introductory STEM Courses." AERA Open 3(4). doi: $10.1177 / 2332858417743754$

Lopatto, David. 2010. Science in Solution: The Impact of Undergraduate Research on Student Learning. Tucson, AZ: Research Corporation for Science Advancement; Washington, DC: Council on Undergraduate Research.

Lovell, Darrell. 2018. "Promoting Original Research: Designing a Course to Produce Quality Undergraduate Political

26 Scholarship and Practice of Undergraduate Research
Science Research in the Community College Setting." Journal of Political Science Education 15: 392-398. doi: 10.1080/15512169.2018.148730

Mandernach, B. Jean. 2015. "Assessment of Student Engagement in Higher Education: A Synthesis of Literature and Assessment Tools." International Journal of Learning, Teaching and Educational Research 12(2): 1-14.

Matz, Rebecca L., Benjamin P. Koester, Stefano Fiorini, Galina Grom, Linda Shepard, Charles G. Stangor, Brad Weiner, and Timothy A. McKay. 2017. "Patterns of Gendered Performance Differences in Large Introductory Courses at Five Research Universities." AERA Open 3(4): 1-12. doi: 10.1177/2332858417743754

McTighe, Jay and Grant P. Wiggins. 2013. Essential Questions: Opening Doors to Student Understanding. Alexandria, VA: ASCD.

Merriam-Webster. 2020. "Research.” Accessed March 23, 2020. https://www.merriam-webster.com/dictionary/research

Rodenbusch, Stacia E., Paul R. Hernandez, Sarah L. Simmons, and Erin L. Dolan. 2016. "Early Engagement in Course-Based Research Increases Graduation Rates and Completion of Science, Engineering, and Mathematics Degrees." CBE-Life Sciences Education 15: ar20. doi: 10.1187/cbe.16-03-0117

Rowland, Susan L., Gwen A. Lawrie, James B. Y. H. Behrendorff, and Elizabeth M. J. Gillam. 2012. "Is the Undergraduate Research Experience (URE) Always Best? The Power of Choice in a Bifurcated Practical Stream for a Large Introductory Biochemistry Class." Biochemistry and Molecular Biology Education 40(1): 46-62. doi: 10.1002/bmb.20576

Schuster, Matthew. 2018. "Undergraduate Research at Two-Year Community Colleges." Journal of Political Science Education 14: 276-280. doi: 10.1080/15512169.2017.1411273

Shortlidge, Erin E., and Sara E. Brownell. 2016. "How to Assess Your CURE: A Practical Guide for Instructors of Course-Based Undergraduate Research Experiences." Journal of Microbiology and Biology Education 17: 399-408. doi: 10.1128/jmbe. v17i3.1103

Spell, Rachel M., Judith A. Guinan, Kristen R. Miller, and Christopher W. Beck. 2014. "Redefining Authentic Research Experiences in Introductory Biology Laboratories and Barriers to Their Implementation." CBE-Life Sciences Education 13: 102-110. doi:10.1187/cbe.13-08-0169

Stanford, Jennifer S., Suzanne E. Rocheleau, Kevin P. W. Smith, and Jaya Mohan. 2017. "Early Undergraduate Research Experiences Lead to Similar Learning Gains for STEM and Non-STEM Undergraduates." Studies in Higher Education 42(1): 115-129. doi: $10.1080 / 03075079.2015 .1035248$

Sweat, Jeffrey, Glenda Jones, Suejung Han, and Susan M. Wolfgram. 2013. "How Does High Impact Practice Predict Student Engagement? A Comparison of White and Minority Students." International Journal for the Scholarship of Teaching and Learning 7(2): ar17. doi: 10.20429/ijsot1.2013.070217

Willison, John, and Kerry O'Regan. 2007. "Commonly Known, Commonly Not Known, Totally Unknown: A Framework for Students Becoming Researchers." Higher Education Research and Development 26: 393-409. doi: 10.1080/07294360701658609 
Prajukti Bhattacharyya

University of Wisconsin-Whitewater, bhattacj@uww.edu

Prajukti (juk) Bhattacharyya is a professor in the Department of Geography, Geology, and Environmental Science at University of Wisconsin-Whitewater $(U W-W)$. Her research interests include the Scholarship of Teaching and Learning. She co-led the Research across Curriculum program with Catherine Chan. She teaches introductoryand upper-level geoscience courses, and actively mentors undergraduate researchers in her lab. She is a councilor in the At-Large Division of the Council on Undergraduate Research (CUR).

Catherine W. M. Chan is executive director of the Office of Research and Sponsored Programs at the University of Wisconsin-Eau Claire. Prior to this appointment, she was a professor in biological sciences and chemistry at $U W-W$. For 10 years, she worked in UW-W's Undergraduate Research Program to broaden participation in mentored research, especially by students from minoritized backgrounds. Integrating student learning and undergraduate research has been the focus of her recent professional development efforts. She is a councilor in CUR's Chemistry Division.

Rocio R. Duchesne, assistant professor in the UW-W Geography, Geology, and Environmental Science Department, holds a BS in biology and graduated from Montclair State University with an MS in statistics and a PhD in environmental management. She has a strong interest in remote sensing and geographic information systems (GIS) applied to terrestrial ecosystems. Her research ranges from mapping shrub expansion in the Arctic, to predicting crop indicators using field spectroscopy data, to modeling groundwater pollution. She enjoys mentoring undergraduate students and incorporating research into teaching.

Aditi Ghosh is an assistant professor in the Department of Mathematics at $U W-W$. She received her PhD from Texas A\&M University-College Station. Her research interests lie in mathematical modeling and bio-mathematics in particular. She is working now on liver disease modeling. She teaches several undergraduate courses in applied mathematics.

Steven N. Girard is an assistant professor at $U W-W$, where he teaches general and inorganic chemistry courses. He earned a PhD in chemistry from Northwestern University and later was an NSF Science, Engineering, and Education for Sustainability Fellow at UW-Madison. The Girard lab investigates nanostructured thermoelectric materials, sustainable synthesis of inorganic compounds, innovative new ways of blowing things up, flux chemistry, and incorporation of chemical research practices into undergraduate STEM courses.

Jonah J. Ralston received his PhD from Michigan State University and is an assistant professor of political science at $U W-W$, where he coordinates the university's public policy and administration program. He also has had academic appointments as faculty sustainability fellow and community-based learning fellow. His most recent research has focused on the degree to which personal values and political beliefs determine voting decisions on bills and ballot measures related to controversial scientific policies.

\section{Want to Review Manuscripts for SPUR?}

Send an email to SPUR@cur.org indicating areas of interest/specialization (e.g., assessment). Experience with qualitative/quantitative methods is highly desired.

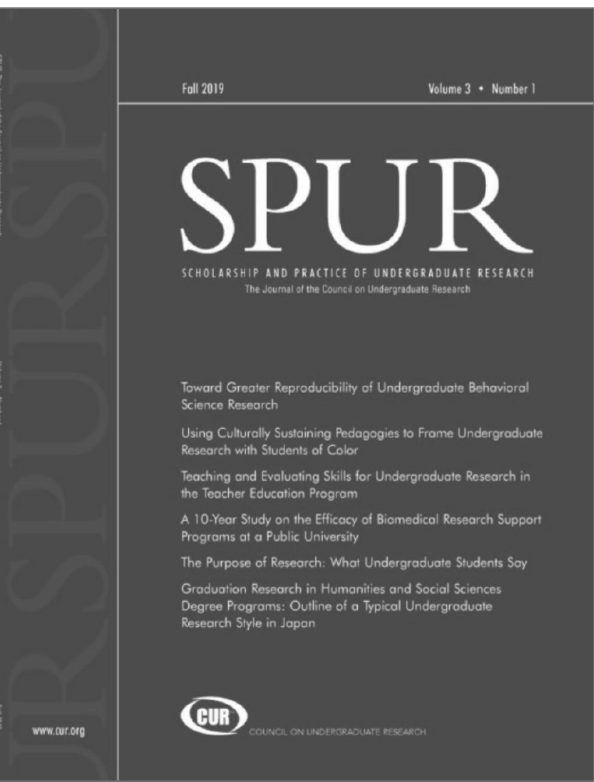

